\title{
GCU
}

Glasgow Caledonian

University

University for the Common Good

\section{Social innovation and the autoimmunity of employability}

Montgomery, Tom

Published in:

Social Policy and Administration

DOI:

10.1111/spol.12585

Publication date:

2020

Document Version

Author accepted manuscript

Link to publication in ResearchOnline

Citation for published version (Harvard):

Montgomery, T 2020, 'Social innovation and the autoimmunity of employability', Social Policy and Administration, vol. 54, no. 7, pp. 1067-1080. https://doi.org/10.1111/spol.12585

\section{General rights}

Copyright and moral rights for the publications made accessible in the public portal are retained by the authors and/or other copyright owners and it is a condition of accessing publications that users recognise and abide by the legal requirements associated with these rights.

Take down policy

If you believe that this document breaches copyright please view our takedown policy at https://edshare.gcu.ac.uk/id/eprint/5179 for details of how to contact us. 


\title{
Social innovation and the autoimmunity of employability
}

Social Policy and Administration: https://doi.org/10.1111/spol.12585

\begin{abstract}
The purpose of this article is to examine social innovation in the field of youth employment. It addresses both the shortcomings of supply-side approaches that are balanced towards issues such as employability and the impact of key demand side issues including low pay and precarity. The empirical analysis is based upon interviews with young people in employment or training with social innovations as well as interviews with senior policymakers and practitioners whose remit covers these issues. The study concludes by reflecting upon how the conduct of employability can operate as an autoimmune function.
\end{abstract}

Keywords: employability, low pay, precarity, social innovation, youth employment

To cite this article please use: Montgomery $\mathrm{T}$. Social innovation and the autoimmunity of employability. Soc Policy Adm. 2020; 1-14.

https://doi.org/10.1111/spol.12585

Dr Tom Montgomery

Yunus Centre for Social Business and Health

Glasgow Caledonian University |

Cowcaddens Road

Glasgow | G4 OBA | Scotland | United

Kingdom

Email: Thomas.Montgomery@gcu.ac.uk 


\section{INTRODUCTION}

The term social innovation has captured the imagination of policymakers (Sinclair \& Baglioni, 2014) across different contexts, straddling a variety of political perspectives while being mobilised as a solution to a variety of public issues of concern and often presented as a remedy that does not involve the same levels of front end financial investment required by welfare states, which have in recent times been under increasing budgetary pressures. Extant research identifies social innovation to be a contested concept (Nicholls \& Murdock, 2012) and even the locus of an ideological conflict between proponents and opponents of neoliberalism (Montgomery, 2016).

The contestation surrounding social innovation reflects the different ways in which the concept and its operationalisation can serve different purposes for different agents. For example, social innovation can be understood through the lens of empowering communities by providing resources that can enable (often marginalised or disadvantaged) communities to (re)define the problems they are facing, identify needs that have not been met by the state or the market and facilitate these needs to be met by innovative actions co-designed and co-produced by the community (Moulaert, Martinelli, Swyngedouw, \& Gonzalez, 2005; Moulaert, Swyngedouw, Martinelli, \& Gonzalez, 2010). On the other hand, social innovation can also be understood through the prism of commodifying social issues that have hitherto been within the scope of the welfare state. From this perspective, the deployment of social innovation becomes difficult to disentangle from efforts to replace public services with social economy organisations, thus introducing market dynamics while allowing policymakers to maintain arms-length control through techniques of public governance (Swyngedouw, 2005). One field where these contrasting perspectives are evident is that of employment, where social innovation in different forms has been operationalised to meet challenges in a context of labour market change.

This article seeks to address the gap in two bodies of existing literature: on the one hand, the social innovation literature in which a lacuna of critical analysis of these practices has been identified in the course of cross-national research (Larsson \& Brandsen, 2016); and on the other hand, the literature on the fragility of contemporary labour markets and its pernicious consequences (Bailey, 2016; Furlong \& Cartmel, 2004; Furlong \& Kelly, 2005; Gallie, Felstead, Green, \& Inanc, 2017; Goos \& Manning, 2007; Pollert \& Charlwood, 2009; Shildrick, MacDonald, Webster, \& Garthwaite, 2012). Although an extensive and growing literature exists on labour market issues, there remains a scarcity of empirical research on the role of social innovation and the intended and unintended consequences, which may flow from it, despite its often unambiguous embrace by policymakers.

The article focuses upon a specific form of social innovation-social enterprise-which extant research has scrutinised in terms of claims that it can challenge neoliberal ideas (Nicholls \& Teasdale, 2017). Social enterprise represents an organisational model of social innovation that involves the establishment of a business that exists for social purposes. This broad definition, however, does not capture the contestation and contextual dynamics, which shape social enterprise across Europe (Borzaga and Defourny, 2001) and the United Kingdom (Pearce, 2003; Teasdale, 2012). Scotland 
is a particularly relevant location for our study given the increasing emphasis placed upon the importance of the social enterprise sector over recent years by the Scottish Government and operationalised into programmes and initiatives across fields including employability and health, reflecting a commitment to 'maintain Scotland's world leadership in social enterprise' (Scottish Government, 2016, p. 80). This builds upon a vibrant history of social enterprise in Scotland, which reaches back to the legacy of Robert Owen in the nineteenth century, and more recently via the models of 'community business' (Roy, McHugh, Huckfield, Kay, \& Donaldson, 2015), which predate a growing agenda among policymakers of different political persuasions in post-devolution Scotland that has resulted in a raft of initiatives (Scottish Executive, 2003, 2004, 2006; Scottish Government, 2008, 2017) that seek to grow the social enterprise sector and which has been identified as reflecting divergence with approaches taken by policymakers in England (Hazenberg, Bajwa-Patel, Roy, Mazzei, \& Baglioni, 2016). One area that has been a focus for social enterprise initiatives that have gained support from the Scottish Government is that of employability. The devolution of new powers following the 2014 independence referendum and the Smith Commission opens the possibility for greater activity from the Scottish Government in this area, albeit on a much-reduced budget.1

However, the valorisation of employability problematizes claims that social enterprise can improve the situation of workers, especially young workers who are at greater risk of low pay and precarious employment (Furlong and Cartmel, 2006) in a labour market context where the use of zero-hour contracts are becoming a common experience for many young people (ONS, 2018).

\section{IMMUNOLOGICAL EMPLOYABILITY}

Tracing the development of the broad ensemble of practices and discourses of employability is beyond the scope of this study. Nevertheless, well-established definitions of employability do exist (see Hillage \& Pollard, 1998) and research has revealed the variegated development of the concept of employability across spatial and temporal contexts (Gazier, 1998). The concept of employability has itself come under scrutiny in the extant literature (McQuaid \& Lindsay, 2005; Peck \& Theodore, 2000) and its mobilisation has been identified as an endeavour marked by the need to fulfil unattainable expectations (Cremin, 2010). Research conducted by Crisp and Powell (2017) has identified, through their analysis of social and employment policies aimed at young people in the United Kingdom between 1978 and 2014, three interrelated themes of an almost exclusive focus upon supply-side employability interventions, increased conditionality and different treatment towards young people in comparison to other age groups. They conclude that almost every intervention during this period has been premised upon the 'supply-side orthodoxy' (identified by McQuaid \& Lindsay, 2005) with the exception of the Future Jobs Fund introduced by the previous Labour Government in 2009.

This article reveals some of the implications of the intensification of supply-side practices and discourses on the capacities of young people to effectively articulate claims for better pay and conditions to employers. As revealed by one policymaker below, support for young people has evolved from a focus primarily upon specific skills 
and competences required by employers, towards a more generic form of employability, focused on attitudes and behaviours (Fugate, Kinicki, \& Ashforth, 2004). This approach reflects to some extent an art of government (Foucault, 2008) that can often be articulated alongside the rhetoric of empowerment.

To understand how such governmentality produces the conduct of employability, we need also to appreciate the circular argument identified by Lemke (2002) that neoliberalism is 'a political project that endeavours to create a social reality that it suggests already exists' (p. 60). Conducts of governance such as employability can transmit to young people norms and values encouraging them to embrace the development of their 'human capital', in the sense explicated by Becker (1962) and critiqued by Foucault (2008). Nevertheless, although the formation of competitive subjectivities can be nurtured through policy with a protective purpose (preparing young people for insecure labour markets), this can also be destructive (shaping young people towards the needs of employers at the expense of their own needs). Following the analysis of the findings from interviews with young people, policymakers and practitioners, a theoretical underpinning was identified to better understand the protective and destructive role that employability plays. That theoretical lens was elicited from the work of Roberto Esposito and his immunological paradigm of biopolitics.

Through a critical analysis of the biopolitics of Foucault (2008), Esposito (2008) constructs a conceptual bridge for what he perceives to be a gap between a positive and protective form of biopolitics and a negative and destructive one. Modifying this conceptualisation, this article argues that in order to tackle youth employment issues, the ensemble of employability mobilised through active labour market policies have served an immunological function.

This immunisation is cultivated via public policies, government agencies and social innovations, which is then internalised by young people with little, if any, resistance given a prevailing consensus that improving their employability can at best broaden the horizons of their labour market opportunities and at worst, do no harm. It is this latter assumption, which this study seeks to contest. Utilising the immunological lens of Esposito (2008), we argue that the modalities of employability can trigger an autoimmune response, where the processes of employability that are mobilised to form a layer of immunity against labour market fragility are intensified to a degree that can act against the young person's ability to voice demands for better pay and conditions, in other words:

'We all know what autoimmune diseases are. They are pathological conditions that occur when our body's immune system becomes so strong that it turns against itself, causing the death of the body... when this does happen, it is not provoked by an external cause but rather by the immune mechanism itself, which is intensified to an intolerable degree' (Esposito \& Hanafi, 2013, p. 86).

\section{METHODOLOGY}

The ensemble of practices and discourses of employability evident in Scotland are very similar to those mobilised in the broader UK context (Berry, 2014; Mizen, 2003; 
Newman, 2011; Peck \& Theodore, 2000) and beyond (Autor \& Houseman, 2010; Barbieri, 2009; Kalleberg, Reskin, \& Hudson, 2000). Therefore, although this study is focused upon a localised geography, and while recognising the limits of this scope, it aims to speak to and provoke theoretical debate and empirical studies of employability in other contexts. With this in mind, we focus upon the experiences of young people engaged in employment and training with social innovations in the west of Scotland, specifically in Glasgow, Inverclyde and Ayrshire. The west of Scotland has been subject to various policy interventions to address not only the problems of youth unemployment but also longstanding issues of poverty and health inequalities (McCartney, Collins, Walsh, \& Batty, 2012; Mooney, McKendrick, Scott, Dickie, \& McHardy, 2016). Communities such as these have not only been suffering inequalities but have also been at the forefront of discourses, which stigmatize poverty (Graham, 2010; MacDonald, Shildrick, \& Furlong, 2014; Mooney, 2009; Shildrick \& MacDonald, 2013; Wiggan, 2012) and reflect those geographies, which are emblematic of the consequences of deindustrialisation that have limited the scope of available opportunities for young people in deprived neighbourhoods (MacDonald \& Marsh, 2005; MacDonald, Shildrick, Webster, \& Simpson, 2005; White \& Green, 2011).

This article is part of a broader study (total $n=33$ ) of the impact of social innovation on youth employment issues in Scotland. Key organisations, which have been active in the field, in some cases for decades, were purposively sampled in order to ensure that interviewees were well placed to voice their experiences of the sector. Moreover, the sampling strategy deliberately aimed to capture variegated experiences across sectors and localities. Broadly speaking, the recruitment of interviewees was straightforward although one social enterprise operated a much more stringent policy and preparatory meetings were held with senior management to provide more detailed information on the study and the type of fieldwork being undertaken. This experience was not replicated anywhere else in the study, even with senior policymakers who had agreed to participate. Perhaps one small difference between interviewees during the fieldwork was the area of informed consent, where more time was taken to ensure the young people participating of their ability to withdraw from the study in comparison to other interviewees, many of whom demonstrated a strong understanding of the research process.

Resulting from the fieldwork, the primary data are drawn from two sources: the first source being semistructured face to face interviews with 19 young people, aged between 16 and 30 and engaged in employment or training with social enterprises in Glasgow, Ayrshire and Inverclyde. The use of face to face interviews is a well-cited method in researching employment issues and was therefore utilised in this study (Furlong \& Cartmel, 2004; MacDonald \& Marsh, 2005). Our second source of primary data stems from interviews (both individual semi-structured interviews and two small focus group interviews) held with senior policymakers who have responsibility in the areas of employment, skills and employability and the third sector as well as with social enterprise practitioners and sector representatives. Across the study on average, the interviews lasted $45 \mathrm{~min}$ with those conducted with policymakers and some practitioners and sector representatives lasting slightly longer than those with young people. Data from the interviews have been coded using NVIVO following a thematic 
analysis of the data (Braun \& Clarke, 2006). The interview schedules were constructed from an analysis of the existing literature and the questions used in the interviews with young people included a focus upon the impact of their employment situation on their plans for the future; if they had ever asked an employer for a pay rise or change in contract or conditions; and more fundamentally if they had enough money to live on. For our interviews with policymakers and practitioners, we asked what they understood to be the key employment issues; what they concluded were the causes of these issues and were asked what social enterprises could offer in comparison to public or private sector organisations. All research participants were given an assurance that their responses would be anonymised to protect their identities.

\section{EMPLOYABILITY IN THE UK AND SCOTLAND}

In our focus group with policymakers, it became clear that although there was an awareness of the importance of both supply and demand side issues, this was a conceptualisation, which seemed to be restricted to the level of government and its partners in socially innovative organisations and not the young workers themselves who were conceptualised more narrowly within the confines of skills and attitudes. In Scotland, there has been an emphasis in recent years on the capabilities of socially innovative organisations to contribute towards remedying issues in the field of employment (Egdell, Dutton, \& McQuaid, 2016; Lindsay, Osborne, \& Bond, 2014), reflecting a broader current in policymaking that such organisations are best placed to be both innovative for civic life and inclusive of 'hard to reach' communities (Fyfe, 2005; Pestoff \& Brandsen, 2010). In its most recent parliamentary programme, the Scottish Government (2016) has highlighted the key role of these organisations and this support was made explicit during a focus group with policymakers:

Marie: We have been committed to the third sector since the SNP came in as a minority Government. Lots of direct support has gone in and that's looking like it will continue.

The Scottish Government have indeed translated their rhetorical support for social innovation into a ten-year social enterprise strategy 2 as well as initiatives such as the Third Sector and Social Enterprise Challenge Fund and Community Jobs Scotland, an employability programme currently in its seventh phase. The devolution of new powers to Holyrood following the independence referendum in 2014, including in the field of employability, may signal an opportunity for divergence, however extant research has questioned the degree of divergence between the constituent parts of the United Kingdom in the area of third sector policy (Alcock, 2012) and suggests a pattern of consistency Tonge (1999) between New Labour and the previous Tory government. For example, Tonge (1999) explains that employer subsidies were also deployed by the Major government and identifies a consensus about training (e.g., employability skills) as the employment policy par excellence. Although enacted years after Tonge's analysis, the Future Jobs Fund introduced in the latter stages of the New Labour government can be seen to sustain both the emphasis on training and employability along with employer subsidies but with an added condition of employer participation: 'community benefit'. Although the Future Jobs Fund was scrapped by the Coalition government, we can detect a continuation of its trajectory with the Community Jobs 
Scotland programme of the SNP government, which has been focused upon the creation of placements for young people in socially innovative organisations such as social enterprises.

The emphasis on the need for young people in Scotland to enhance their employability has been the subject of various policy interventions, initiatives and reports. A driving force in the ensemble of youth employability has been the Commission for Developing Scotland's Young Workforce, set up in January 2013 by the Scottish Government with key objectives including the need to 'ensure young people at all levels of education understand the expectations of employers' and 'to achieve a culture of real partnership between employers and education, where employers view themselves as co-investors and co-designers rather than simply customers' (Scottish Government, 2014, p. 4). The

findings and recommendations of the Commission have been used to inform the educational programme, which has come to define school education in Scotland: the Curriculum for Excellence.3 These developments come amidst a host of other initiatives including the creation of a certificate of work readiness. 4 Despite devolution, the Scottish context is of course enmeshed within the broader UK policy setting. At UK level, the emphasis on employability through skills development has been matched in recent years by an emphasis on attitudes exemplified at times by powerful discourses such as the 'cultures of worklessness' (DWP, 2012) trope critiqued by MacDonald et al. (2014) who conclude that although erroneous, have proven resilient to opposing evidence. In the course of our interviews, young people were keen to highlight the efforts they had made to gain employment:

Bernadette: I applied for 142 jobs and heard back from two. It was ridiculous and one of them was a zero hour contract and the other one was night shift in KFC. That was all I got back!

Martin: About sixty applications or something, I'm just constantly sending them off and...I don't know if my CV is wrong or whatever else but l've managed to get other jobs with the same CV.

Douglas: I applied for that (an apprenticeship) and they said there was 500 or 600 applicants, so I never even got an interview.

In fact, the young people interviewed demonstrated a consistent concern with cultivating their employability. These accounts echoed the experience of one of the programme managers in a social enterprise who explained that throughout his experience of delivering employment initiatives in the west of Scotland there was scarce evidence of a 'culture of worklessness':

Findlay: I have in my twelve years only met two people who are not wanting to work... most people I see actually want to work.

Socially innovative organisations have also been involved in the delivery of training opportunities which young people have been signposted to by the Department of Work and Pensions and have therefore been recognised across devolved and central government as important players in the enhancement of employability of young 
people. Researching the Scottish case revealed that socially innovative organisations are viewed as an essential component in the ensemble of employability. However, although these organisations are distinguished by a social mission, their enmeshment in the ensemble of employability could mitigate against any potential social impact if the intensification of employability as an immune mechanism against labour market fragility can result in a form of autoimmunity that can subdue disagreement with pay and conditions.

\section{THE POLICYMAKING PERSPECTIVE}

One area explored during the interviews was to understand the reasoning behind the support from policymakers for socially innovative organisations to address youth employment issues. The response from one official, whose remit was the third sector, was to point towards the example of social enterprise, explaining that:

Marie: it's about a business model that does more than just deliver profit for shareholders... that offers opportunities to a range of individuals who maybe wouldn't normally get the chance to work and train and learn. So it's about all of these things, so it's a good thing to do.

The views expressed by this official are consistent not only with the direction of travel of the Scottish Government in terms of the intersection between social innovation and employability but are also congruent with broader policy currents and the views elicited from practitioners and sector representatives. Nevertheless, although policymakers can perceive social innovation as a 'good thing to do', a key question is whether it can effectively address the root problems of youth employment issues. During the interviews, it became clear that policymakers were conscious of the impact of the global financial crisis on youth employment with one official explaining that:

Richard: ...the recession has been a major contributing factor. It puts young people at a particular disadvantage.

Moreover, there was also an awareness of the changing nature of the labour market and during the interviews some policymakers asserted that they would discourage employers from the use of non-standard forms of employment such as zero-hour contracts mirrored by a degree of certainty that such types of insecurity were not to be found in any of the youth employment programmes currently being implemented in Scotland. Moreover, in terms of the quality of employment, one official was keen to stress that:

Nicholas: ...there's quite a senior group looking at various aspects of this about improving what's happening in the workplace, making better jobs for people, all that kind of thing. So there is a whole side of the division looking at that kind of thing, creating better jobs.

Therefore, our interviews indicated that there is a degree of awareness amongst policymakers in Scotland that there are issues both with demand and with the quality of employment available to young people, evidenced in recent times by the establishment of a Fair Work Convention.5 Against this backdrop, we then must ask how to best prepare young people to navigate this labour market context. When 
pressed during our interviews on what young people could do to secure employment, one official explained that:

Richard: It's not the technical skills to do a particular job which are particularly missing. I think employers have a fair degree of confidence that the educational institutions are providing their students with their requisite levels to do particular jobs, it's the more sort of generic employability skills.

This statement relates somewhat to the conclusion reached by Cremin (2010) that in the contemporary labour market there is an intangible sense of employability that workers are expected to strive for, but which always remains elusive. The same official added that these types of 'employability skills' could simply mean the young person appreciating that they had to turn up for work on time. Nevertheless, later in the discussion, his colleague expressed frustration that despite efforts to encourage third sector organisations to develop their workforce, particularly young workers, there had been a tendency to focus on bringing in new workers on a temporary basis, adding that:

Marie: I'm pretty jaded about a lot of this stuff actually...I remember before 1990 we had a Youth Guarantee, every young person gets the guarantee of... and you think well how many years down the line? Have we moved forward?

These concerns are somewhat vindicated by research conducted by Crisp and Powell (2017) who elaborate the variety of employability programmes aimed at young people in the United Kingdom long before devolution, indeed since the late 1970s, suggesting the existence of an almost permanent crisis. What perhaps connects all of these programmes and initiatives as well as the contemporary efforts of the Scottish Government is that the young people at the centre of these policies have been subject to various interventions. In the case of the Scottish Government, social innovation has been mobilised as part of broader efforts to intensify the immunity of young people from the impact of fragile labour markets. The consistent emphasis therefore has been to cultivate 'employable' young people rather than equipping them to voice their own needs and demands. The absence of the capacity or willingness to effectively voice one's own needs was consistently elicited from the interviews with young people in employment or training with socially innovative organisations in the west of Scotland.

\section{PERSPECTIVES OF YOUNG PEOPLE}

The young people interviewed were engaged in either employment or training with socially innovative organisations in the west of Scotland, which were involved in diverse sectors such as social care, hospitality, call centre work and the creative sector. Some described themselves as 'permanently' employed with a social enterprise and indeed they had been employed beyond their original placement; however, this description somewhat stretched the concept of permanence given the unpredictable number of hours of work available to them or indeed any security of occupational status. There were some who were engaged in the Community Jobs Scotland programme, which provided them with a minimum number of hours per week but these hours were more akin to part-time rather than full-time employment and other interviewees were engaged on a training scheme for which they continued to receive 
their unemployment benefits (e.g., Jobseeker's Allowance). Despite the diversity of their contractual or sectoral situations, many of the young people described their employment experiences along very similar lines, with a spectre of insecurity emerging from their descriptions and recollections. These variegated experiences present a complex picture that resonates with the conclusion reached by Lazzarato (2009), that, 'it is not the same insecurity for everyone whatever the level and conditions of employment, yet a differential of fear runs along the whole continuum' (p. 120). What was particularly revealing during the interviews with young people was the way in which they grappled with the insecurity that comes with navigating fragile labour markets.

What became striking during the interviews was the absence of any real concern from many of the young people about the cyclical stop and start nature of their labour market experiences. What is crucial to recognise here is how the intensification of employability as discourse and practice corresponds with the fragility of the labour markets being navigated by young people and fixes attention to the self-marketing (Fogde, 2011) of the individual young person rather than broader structural issues of the quality of available employment. In fact, when probed about whether or not the temporary nature of their employment impacted upon their ability to make plans for their future some of the young people were evasive of the question, a few denied that the precarity they had or were experiencing had any impact on their capacity to make plans, despite the often quite stark insecurity they were encountering. Although these young people were unwilling to elaborate much further, existing research in the United Kingdom on defensive strategies undertaken by those in poverty to counter the stigma which accompanies it may prove a useful avenue of investigation (Garthwaite, 2016; Patrick, 2016). Among those young people who did provide more elaborate answers, there was a recurring theme in their interviews: that they paid little attention towards their future situation. As was reflected by responses from two interviewees involved in the Community Jobs Scotland programme:

Patrick: ...just don't see the point in worrying about it the now. I've got a job the now so what's the point in trying to stress yourself out just now, still got another four months, so...

Tony: It's only a month in, I'll probably worry about it when it's about six months, you know, five and a bit months down the line and then go, 'aye, by the way, what am I doing next week?'

This outlook was not confined to those participating on the Community Jobs Scotland programme as other young people we spoke to not involved in CJS exhibited the same attitudes towards planning for the future:

Martin: There is no point being unhappy because you never know when it could end, so no, I'm not going to make plans the now. Take it as it comes. When you make plans, things go wrong.

Donna: I can't think that far ahead.

Interviewer: Why not? 
Donna: I just go day by day.

Perhaps one explanation for the unwillingness to confront the future may be explained by the response of two interviewees as to the effect insecurity has had on their capacity to think about the future and the constant state of alert that comes with precarity:

Iona: Everything. You can't book a holiday, you can't buy a house, you can't do anything, kind of just... any spare cash, saving, just in case.

Tony: It's always in the back of my mind, you can get too comfortable with something and boom, it's gone.

These experiences reflect the findings of research by Standing (2011) who has described a generation of workers as a class in the making or 'precariat' for whom '...there is no shadow of the future' (p. 12). During the interviews, it also became apparent that there was scarce evidence of solidaristic ties being built between those young people either in employment or training, mirroring to some extent the findings of research elsewhere in the United Kingdom, which reveals the tenuous nature of building friendships in the contemporary workplace (Winlow \& Hall, 2009). The unwillingness from the young people interviewed to raise employment issues with their employer or training provider manifested itself across the different socially innovative organisations, their sectors, their specific geographical location and whether the young person was currently in employment or training. Moreover, the young people interviewed consistently indicated a reluctance to voice needs or concerns to employers past or present and across different employment issues such as levels of pay, contract and working conditions.

One of the key issues confronting young people entering the labour market is that of the level of pay and in the local labour markets where the young people interviewed are located low pay has been a consistent issue for workers of all ages and has itself been the subject of policy interventions.6 The geographic locations where the interviews were conducted have also been at the frontline of austerity measures and welfare reforms, which have both sucked money from circulating in the local economies and increased the potential supply of workers (Beatty \& Fothergill, 2014). None of the young people interviewed indicated a willingness to raise the issue of pay levels with employers even though some of those on a training scheme explained that they knew they would not be able to sustain themselves without parental support on that income, a growing experience among young people in the United Kingdom (ONS, 2019). Nevertheless, there was a degree of reluctance amongst the young people we interviewed about voicing needs or demands such as pay rises with employers, which one young person demonstrated when asked if she had ever requested a pay rise:

Donna: Not really, because we got pay rises every October anyway when the national rate went up so...

Another young person when probed on this matter emphasised that there was no room for any discussion over the allowance he had received on a previous programme he had participated in. 
Blair: No, that's your fixed pay. That's fixed pay basically, it's [a training organisation] that pays it, its $£ 11$ per day and that's just it basically.

Some explanation for this unwillingness to broach the subject of pay increases emerged when some of the interviewees indicated an awareness of a power imbalance between them and their employer or prospective employer, exacerbated by the mismatch between the supply of young workers and the demand in the labour market:

Keith: ...they're ruthless, they want what they want and there is no...there's no backtracking to that, they want what they want.

Power asymmetries can help explain decent pay, which is crucial in order for the young people to sustain some quality of living and to facilitate their ability to socialise but they can also explain another key issue for many young people in the United Kingdom: the issue of employment security with young people disproportionately having been at the sharp end of the rise of non-standard forms of employment such as zero hour contracts (ONS, 2018). In terms of employment security, the young people interviewed recounted their experiences of the fragility of their positions and the often ad-hoc manner in which their employment had been terminated in the past as these respondents illustrate:

Patrick: ...they just paid us off. Not even paid us off, just let my contract end and that was it.

Tony: There was no contract...you'll be working away and you'll get the tap on the shoulder and told, 'go to the auditorium' and you know what that means, that means you're fired.

Moreover, one of the participants, who had undertaken two placements via Community Jobs Scotland, articulated her frustration with the temporary nature of the scheme when recounting her experiences, one with a charity and another with a credit union:

Rhona: The credit union took me on because they weren't paying my wages, my wages were being paid [by the programme], they couldn't afford me obviously, then after that it was just back to square one again.

Interviewer: Did they say to you that there may be a chance of work there?

Rhona: No, they can't afford it, they already had to pay somebody off that they were paying themselves because they just couldn't afford it.

Interviewer: What about the charity, did they say anything different?

Rhona: No.

Interviewer: Just the contract ended...

Rhona: That was it, over, aye.

The stop and start nature of the experience on these placements led the young person to draw conclusions about the wider impact of the scheme in its capacity to provide sustainable employment opportunities: 
Rhona: It's no good because you go in there for the six months and that's you just getting used to the job and then....you're gone.

This was an experience mirrored by another young person on a similar scheme with another organisation who explained that he too found that there was little opportunity to progress into more sustainable work with the organisation due to a lack of funding. The young person even went so far as to empathise with the organisation's inability to provide him with a permanent position:

Blair: She's tried to even get me a job with [the social enterprise] but because there's no jobs going...she tells me she feels bad and that for it and I'm like that, "but it's not your problem, you've done so much to help me". They'll do anything to help you as long as you're willing to put in the work, but...

Interviewer: The job's not there?

Blair: Aye, the job's not there, but nothing they can do about it.

To some extent this reflects the findings of research by Peck (2002) who explains that in such programmes, 'both participants and program managers are on treadmills of someone else's making, coerced and constrained by a combination of competitive relations and superordinate rule systems' (p. 350). Nevertheless, we should be careful here to note that even though both the participants and the organisations are both experiencing insecurity, the latter will often be better resourced and better placed to articulate their needs than the former. If the socially innovative organisation simply does not have the capacity to provide sustainable employment, and this reflects the findings of interviews with some young people, it is difficult to understand how any further intensification of employability skills or attitudes could have in these cases improved employment opportunities.

Moreover, the limit between the rhetorical expectations placed upon the third sector and its actual capacity to provide secure full time employment has been revealed to some extent by existing research that has critiqued policy narratives which have exaggerated the growth of social innovation in the form of social enterprise (Teasdale, Lyon, \& Baldock, 2013). Further still, more recent research conducted in partnership with the sector in the form of a 'census' of social enterprise in Scotland has revealed the precarious financial tightrope that many of these organisations are navigating given the importance of grant funding for some organisations at a time of constraints on public spending and the use of zero hour contracts among such organisations (15 per cent) at a rate almost double that of SMEs (8 per cent) in Scotland (Social Value Lab, 2017). The findings from this study in the west of Scotland also mirror to some extent the conclusions drawn by Amin (2009) in the south west of England; that it is overly ambitious, even unrealistic to expect organisations such as social enterprises to transform the labour market opportunities of disadvantaged young people. There was also an indication given in at least one of the interviews with a young person employed by a socially innovative organisation that there may be a potential unintended consequence from job placement programmes:

Iona: Yeah. So, basically they hire them, cut everybody else's hours, we get less pay...yeah, fair enough the company's benefiting, but the people aren't 
benefiting. Everywhere I've seen. Nearly everybody I knows hours have been cut because they've hired them.

Although confined to one source, this reflection points towards a potential lack of consensus between those young people working in socially innovative organisations and those policymakers we spoke to in our interviews who dismissed any suggestion that precarity may exist within employability programmes which they are coordinating.

\section{CONCLUSIONS}

A key aim of this article has been to challenge the assumption that intensifying the conduct of employability with young people navigating fragile labour markets can do no harm. Instead, what employability does, to return to Foucault (2008), is to cultivate a type of conduct that acts as a form of immunity. What has been set out here is how that immunity is intensified in a specific setting for specific groups, namely the use of social innovations to deliver employment and employability programmes for young people. This immunity encourages young workers to build their own personal brand and to market this brand to prospective employers. The risk of doing so in a context of labour market fragility means young people may relegate their needs (for security or better pay) in order to appease not one employer but a 'spectral boss' (Cremin, 2010). Employability programmes can formalise this process and the use of socially innovative organisations helps make this process more palatable, so much so that it has been embraced as a potential solution even by policymakers who demonstrate an awareness of the precarious nature of contemporary labour markets which young people must navigate. Indeed, even our young interviewees sometimes empathised with the financial challenges faced by the social enterprise with whom they were in employment or training yet rarely indicated an awareness of the challenges faced by their fellow workers or trainees.

Most if not all the young people interviewed were complimentary about the training scheme or employment they were engaged in with a socially innovative organisation and indeed during our research it became apparent that the setting is often relaxed, less formal and supportive. Despite this, however, those young people we spoke to who were in employment or training in these organisations were still reluctant to voice issues of pay or employment security. Instead, through the conduct of employability young people are to find agency in their capacity to self-market as employable subjects to sustain their current employment or succeed in their job search. Thus, success and failure in securing good quality employment risk being reduced to the cultivation of individual level strategies (Sharone, 2007) rather than fully responding to labour market fragility by focusing expertise and resources on educating young workers about their rights as well as their responsibilities. Narrowing the parameters of agency for young workers to conducts of employability may also help explain the absence of a 'shadow of the future' (Standing, 2011) from most young people interviewed in this study and the scarcity of solidarity with their peers. Employability focused approaches to address the employment issues of young workers are thus at risk of developing a form of protection or 'immunisation' to such an intensity that it triggers an autoimmune reaction where, 'the protective barriers against the outside begin to represent a greater risk than what they are intended to prevent' (Esposito, 2008, p. 86). 
Given the focus of many of these efforts in disadvantaged neighbourhoods, we should consider the broader implications of our findings for tackling inequalities in a context where addressing the growing gap between the richest and poorest schoolchildren has become a policy priority.7 Our findings do not suggest that there is no role for socially innovative organisations to assist young people with employment issues. Indeed, social innovation practitioners we spoke to conveyed a detailed understanding of the nature and scale of the challenges young people were facing in contemporary labour markets as well as the difficulties of overcoming entrenched inequalities. Furthermore, although tailored support for young people and more vulnerable groups is likely to be beneficial, this could be improved by more careful appreciation of the negative impact of individualising responsibility for demand side issues in the labour market in a context where policymakers are already aware of the connections between poverty, stigma and the social isolation of young people (Scottish Parliament, 2015).

Although this study is limited in scope and scale by its qualitative focus on a localised geography and

organisational type, comparable research in other contexts could provide the building blocks for understanding the different roles that socially innovative organisations could play beyond employability, one which more fully embraces a community (Moulaert et al., 2010) rather than individualised approach and which commits resources to educating young workers about their rights as well as their responsibilities.

\section{ENDNOTES}

$1 \mathrm{http}: / /$ news.gov.scot/news/employability-services-budget-slashed

2 http://www.gov.scot/Publications/2016/12/4404/0

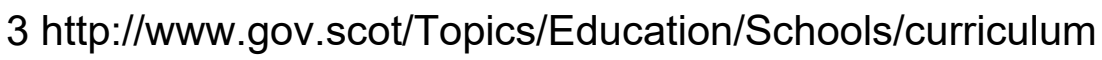

4 http://www.sqa.org.uk/sqa/64560.html

5 https://www.fairworkconvention.scot/

$6 \mathrm{http} / / / w w w . g o v . s c o t / T o p i c s / B u s i n e s s-I n d u s t r y /$ Workingtogether/LivingWage

7 http://www.gov.scot/Topics/Education/Schools/Raisingeducationalattainment

\section{REFERENCES}

Alcock, P. (2012). New policy spaces: The impact of devolution on third sector policy in the UK. Social Policy \& Administration, 46(2), 219-238.

Amin, A. (2009). Extraordinarily ordinary: Working in the social economy. Social Enterprise Journal, 5(1), 30-49. 
Autor, D. H., \& Houseman, S. N. (2010). Do temporary-help jobs improve labor market outcomes for low-skilled workers? Evidence from "work first". American Economic Journal: Applied Economics, 2, 96-128.

Bailey, N. (2016). Exclusionary employment in Britain's broken labour market. Critical Social Policy, 36(1), 82-103.

Barbieri, P. (2009). Flexible employment and inequality in Europe. European Sociological Review, 25(6), 621-628.

Beatty, C., \& Fothergill, S. (2014). The local and regional impact of the UK's welfare reforms. Cambridge Journal of Regions, Economy and Society, 7(1), 63-79.

Becker, G. S. (1962). Investment in human capital: A theoretical analysis. The Journal of Political Economy, 5, 9-49.

Berry, C. (2014). Quantity over quality: A political economy of 'active labour market policy' in the UK. Policy Studies, 35(6), 592-610.

Braun, V., \& Clarke, V. (2006). Using thematic analysis in psychology. Qualitative Research in Psychology, 3(2), 77-101.

Borzaga, C., \& Defourny, J. (2001). 'Conclusions. Social enterprises in Europe: A diversity of initiatives and prospects'. In J. Defourny and C. Borzaga (Eds), The emergence of social enterprise. Routledge. London. p 350-370.

Cremin, C. (2010). Never employable enough: The (im)possibility of satisfying the boss's desire. Organization, 17(2), 131-149.

Crisp, R., \& Powell, R. (2017). Young people and UK labour market policy: A critique of 'employability' as a tool for understanding youth unemployment. Urban Studies, 54(8), 1784-1807.

Department for Work and Pensions (DWP). (2012). Social justice: Transforming lives. London: The Stationery Office.

Egdell, V., Dutton, M., \& McQuaid, R. (2016). Third sector experiences of work programme delivery. Journal of Social Policy, 45(4), 729-746.

Esposito, R. (2008). Bios: Biopolitics and philosophy (Vol. 4). Minneapolis, USA and London, UK: U of Minnesota Press.

Esposito, R., \& Hanafi, Z. (2013). Community, immunity, biopolitics. Angelaki, 18(3), 83-90.

Fogde, M. (2011). Governing through career coaching: Negotiations of self-marketing. Organization, 18(1), 65-82.

Foucault, M. (2008). The birth of biopolitics: Lectures at the Collège de France, 19781979. Basingstoke, Hampshire: Palgrave Macmillan.

Fugate, M., Kinicki, A. J., \& Ashforth, B. E. (2004). Employability: A psycho-social construct, its dimensions, and applications. Journal of Vocational Behavior, 65(1), 1438. 
Furlong, A., \& Cartmel, F. (2004). Vulnerable young men in fragile labour markets: Employment, unemployment and the search for long-term security. York: Joseph Rowntree Foundation.

Furlong, A., \& Cartmel, F. (2006). Young people and social change. UK: McGraw-Hill Education.

Furlong, A., \& Kelly, P. (2005). The Brazilianisation of youth transitions in Australia and the UK? Australian Journal of Social Issues, 40(2), 207-225.

Fyfe, N. R. (2005). Making space for 'neo-communitarianism'? The third sector, state and civil society in the UK. Antipode, 37, 536-557.

Gallie, D., Felstead, A., Green, F., \& Inanc, H. (2017). The hidden face of job insecurity. Work, Employment and Society, 31(1), 36-53.

Garthwaite, K. (2016). Stigma, shame and 'people like us': An ethnographic study of foodbank use in the UK. Journal of Poverty and Social Justice, 24(3), 277-289.

Gazier, B. (1998). Employability: Definitions and trends. In B. Gazier (Ed.), Employability: Concepts and policies. Berlin: European Employment Observatory.

Goos, M., \& Manning, A. (2007). Lousy and lovely jobs: The rising polarization of work in Britain. The Review of Economics and Statistics, 89(1), 118-133.

Graham J (2010) The Scheme: gritty TV or poverty porn? The Guardian. Friday 28th May 2010. Retrieved from https://www.theguardian.com/tv-andradio/tvandradioblog/2010/may/28/the-scheme-bbc

Hazenberg, R., Bajwa-Patel, M., Roy, M. J., Mazzei, M., \& Baglioni, S. (2016). A comparative overview of social enterprise 'ecosystems' in Scotland and England: An evolutionary perspective. International Review of Sociology, 26(2), 205-222.

Hillage, J., \& Pollard, E. (1998). Employability: Developing a framework for policy analysis. London: DfEE.

Kalleberg, A. L., Reskin, B. F., \& Hudson, K. (2000). Bad jobs in America: Standard and nonstandard employment relations and job quality in the United States. American Sociological Review, 65(2), 256-278.

Larsson, O. S., \& Brandsen, T. (2016). The implicit normative assumptions of social innovation research: Embracing the dark side. In T. Brandsen, S. Cattacin, A. Evers, \& A. Zimmer (Eds.), Social innovation in the urban context. Berlin: Springer.

Lazzarato, M. (2009). Neoliberalism in action inequality, insecurity and the reconstitution of the social. Theory, Culture \& Society, 26(6), 109-133.

Lemke, T. (2002). Foucault, governmentality, and critique. Rethinking Marxism, 14(3), 49-64.

Lindsay, C., Osborne, S. P., \& Bond, S. (2014). The 'new public governance' and employability services in an era of crisis: Challenges for third sector organizations in Scotland. Public Administration, 92(1), 192-207. 
MacDonald, R., \& Marsh, J. (2005). Disconnected youth?: Growing up in Britain's poor neighbourhoods. Basingstoke: Palgrave Macmillan.

MacDonald, R., Shildrick, T., \& Furlong, A. (2014). Benefits street' and the myth of workless communities. Sociological Research Online, 19, 3. https://doi.org/10.5153/sro.3438

MacDonald, R., Shildrick, T., Webster, C., \& Simpson, D. (2005). Growing up in poor neighbourhoods: The significance of class and place in the extended transitions of 'socially excluded' young adults. Sociology, 39(5), 873-891.

McCartney, G., Collins, C., Walsh, D., \& Batty, G. D. (2012). Why the scots die younger: Synthesizing the evidence. Public Health, 126(6), 459-470.

McQuaid, R. W., \& Lindsay, C. (2005). The concept of employability. Urban Studies, 42(2), 197-219.

Mizen, P. (2003). The best days of your life? Youth, policy and Blair's new labour. Critical Social Policy, 23(4), 453-476.

Mooney, G. (2009). The 'broken society' election: Class hatred and the politics of poverty and place in Glasgow east. Social Policy and Society, 8(04), 437-450.

Mooney, G., McKendrick, J., Scott, G., Dickie, P., \& McHardy, F. (2016). Poverty in Scotland 2016: Tools for transformation. London: Child Poverty Action Group.

Montgomery, T. (2016). Are social innovation paradigms incommensurable?. Voluntas: International Journal of Voluntary and Nonprofit Organizations, 27(4), 19792000.

Moulaert, F., Martinelli, F., Swyngedouw, E., \& Gonzalez, S. (2005). Towards alternative model (s) of local innovation. Urban Studies, 42(11), 1969-1990.

Moulaert, F., Swyngedouw, E., Martinelli, F., \& Gonzalez, S. (Eds.). (2010). Can neighbourhoods save the City?: Community development and social innovation. Abingdon, Oxon: Routledge.

Newman, I. (2011). Work as a route out of poverty: A critical evaluation of the UK welfare to work policy. Policy Studies, 32 (2), 91-108.

Nicholls, A., \& Murdock, A. (2012). The nature of social innovation. In A. Nicholls \& A. Murdock (Eds.), Social innovation: Blurring boundaries to reconfigure markets (pp. 130). Basingstoke and New York: Palgrave Macmillan.

Nicholls, A., \& Teasdale, S. (2017). Neoliberalism by stealth? Exploring continuity and change within the UK social enterprise policy paradigm. Policy \& Politics, 45(3), 323341.

Office for National Statistics (2018) (2018) Contracts that do not guarantee a minimum number of hours: April 2018.

Office for National Statistics (ONS) (2019) Families and Households in the UK: 2019. 
Patrick, R. (2016). Living with and responding to the 'scrounger' narrative in the UK: Exploring everyday strategies of acceptance, resistance and deflection. Journal of Poverty and Social Justice, 24(3), 245-259.

Pearce, J. (2003). Social Enterprise in Anytown. London: Calouste Gulbenkian Foundation.

Peck, J. (2002). Political economies of scale: Fast policy, interscalar relations, and neoliberal workfare. Economic Geography, 78(3), 331-360.

Peck, J., \& Theodore, N. (2000). Beyond 'employability. Cambridge Journal of Economics, 24(6), 729-749.

Pestoff, V., \& Brandsen, T. (2010). Public governance and the third sector: Opportunities for co-production and innovation? In S. P. Osborne (Ed.), The new public governance? (pp. 223-236). London: Routledge.

Pollert, A., \& Charlwood, A. (2009). The vulnerable worker in Britain and problems at work. Work, Employment \& Society, 23 (2), 343-362.

Roy, M. J., McHugh, N., Huckfield, L., Kay, A., \& Donaldson, C. (2015). "The most supportive environment in the world"? Tracing the development of an institutional 'ecosystem' for social enterprise. Voluntas: International Journal of Voluntary and Nonprofit Organizations, 26(3), 777-800.

Scottish Executive. (2003). A review of the Scottish executive's policies to promote the social economy. Edinburgh: Scottish Executive.

Scottish Executive. (2004). Futurebuilders Scotland: Investing in the social economy. Edinburgh: Scottish Executive.

Scottish Executive. (2006). A social enterprise strategy for Scotland: A consultation. Edinburgh: Scottish Executive.

Scottish Government (2008). Enterprising Third Sector Action Plan 2008-2011. Scottish Government, Edinburgh.

Scottish Government. (2014). Education working for all! Commission for developing Scotland's young workforce final report. Edinburgh: Scottish Government.

Scottish Government. (2016). A plan for Scotland: The government's programme for Scotland 2016-2017. Edinburgh: Scottish Government.

Scottish Government. (2017). Building a sustainable social enterprise sector in Scotland action plan 2017-20. Edinburgh: Scottish Government.

Scottish Parliament (2015) Equal opportunities committee, Age and Social Isolation, 5th Report, 2015. Session 4

Sharone, O. (2007). Constructing unemployed job seekers as professional workers: The depoliticizing work-game of job searching. Qualitative Sociology, 30(4), 403-416. 
Shildrick, T., \& MacDonald, R. (2013). Poverty talk: How people experiencing poverty deny their poverty and why they blame 'the poor'. The Sociological Review, 61(2), 285-303.

Shildrick, T. A., MacDonald, R., Webster, C., \& Garthwaite, K. (2012). Poverty and insecurity: Life in low-pay, no-pay Britain. Bristol: Policy Press.

Sinclair, S., \& Baglioni, S. (2014). Social innovation and social policy—promises and risks. Social Policy and Society, 13(03), 469-476.

Social Value Lab (2017) Social Enterprise in Scotland: Census 2017.

Standing, G. (2011). The precariat: The new dangerous class. Arnold: Hodder.

Swyngedouw, E. (2005). Governance innovation and the citizen: The Janus face of governance-beyond-the-state. Urban Studies, 42(11), 1991-2006.

Teasdale, S. (2012). What's in a name? Making sense of social enterprise discourses. Public policy and administration, 27(2), 99-119.

Teasdale, S., Lyon, F., \& Baldock, R. (2013). Playing with numbers: A methodological critique of the social enterprise growth myth. Journal of Social Entrepreneurship, 4(2), 113-131.

Tonge, J. (1999). New packaging, old deal? New labour and employment policy innovation. Critical Social Policy, 19(2), 217-232.

White, R. J., \& Green, A. E. (2011). Opening up or closing down opportunities?: The role of social networks and attachment to place in informing young peoples' attitudes and access to training and employment. Urban Studies, 48(1), 41-60.

Wiggan, J. (2012). Telling stories of 21st century welfare: The UK coalition government and the neo-liberal discourse of worklessness and dependency. Critical Social Policy, 32(3), 383-405.

Winlow, S., \& Hall, S. (2009). Living for the weekend: Youth identities in Northeast England. Ethnography, 10(1), 91-113 